\title{
Circulating melanoma cells and survival in metastatic melanoma
}

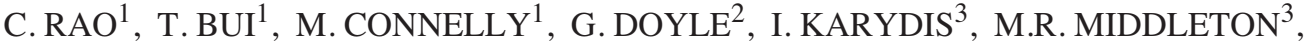

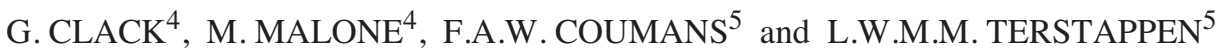 \\ ${ }^{1}$ Veridex LLC, Huntingdon Valley; ${ }^{2}$ Clinical Consultant, Radnor, USA; ${ }^{3}$ Department of Oncology, University of Oxford; \\ ${ }^{4}$ AstraZeneca, Cheshire, UK; ${ }^{5}$ Medical Cell BioPhysics, University of Twente, Enschede, The Netherlands
}

Received September 1, 2010; Accepted October 21, 2010

DOI: $10.3892 /$ ijo.2011.896

\begin{abstract}
A validated assay for the enumeration of circulating melanoma cells (CMCs) may facilitate the development of more effective therapies for metastatic melanoma patients. In this study CD $146^{+}$cells were immunomagnetically enriched from $7.5 \mathrm{ml}$ of blood. Isolated cells were fluorescently stained with DAPI, anti-molecular weight melanoma-associated antigen (HMW-MAA), anti-CD45 and CD34 and Ki67. CMCs were identified as CD146+, ${ }^{+}$MW-MAA ${ }^{+}, \mathrm{CD}^{2} 5^{-}$, $\mathrm{CD}^{-} 4^{-}, \mathrm{Ki}^{-/+}$cells. Eighty-eight percent of spiked SKMEL28 cells in $7.5 \mathrm{ml}$ blood were recovered. In all 55 healthy donors $\leq 1 \mathrm{CMCs}$ were detected in $7.5 \mathrm{ml}$ of blood. A retrospective analysis was conducted comparing CMC counts and overall survival in 79 blood samples from 44 melanoma patients. CMCs ranged from 0 to 8,042 per $7.5 \mathrm{ml}$. Two or more CMCs were detected in $18(23 \%)$ of the patients and $30-100 \%$ (mean $84 \%$ ) of the CMCs expressed the proliferation marker Ki67. Patients with $\geq 2$ CMCs per $7.5 \mathrm{ml}$ of whole blood, as compared with the group with $<2 \mathrm{CMCs}$, had a shorter overall survival (2.0 months vs. 12.1 months, $\mathrm{P}=0.001$ ).
\end{abstract}

\section{Introduction}

Evidence of the biological and clinical significance of nonhematogenous circulating tumor cells (CTC) is rapidly increasing. The use of the standardized CellSearch ${ }^{\circledR}$ system to detect these rare tumor cells in blood of patients with a variety of metastatic carcinomas has facilitated this process (1) by permitting prospective multicenter studies in metastatic breast, colorectal and prostate cancer (2-4). These data have been further validated by other independent studies (5-7). Perhaps most importantly, comparison with imaging modalities

Correspondence to: Leon W.M.M. Terstappen, University of Twente, Faculty of Science and Technology, MIRA institute, Department of Medical Cell BioPhysics, Building Care, P.O. Box 217, 7500 AE Enschede, The Netherlands

E-mail: 1.w.m.m.terstappen@utwente.nl

Key words: circulating tumor cells, melanoma, metastasis, minimal residual disease shows that circulating tumor cells (CTC) may be a more effective means of monitoring metastatic breast cancer patients $(8,9)$.

As with carcinomas, treatment of advanced melanoma is complicated by its heterogeneous histopathology and continuing mutation during disease progression. An accurate and reliable method for monitoring the number of $\mathrm{CMC}$ in melanoma patients could facilitate the development of more effective therapies. To date, data generated by either RTPCR $(10,11)$ or cytometry $(12,13)$ have demonstrated that the presence of CMC may have prognostic value in patients diagnosed with melanoma. Conflicting results from these studies, possibly due to the use of different methodologies, has highlighted the need for CMC assay standardization before clinical studies can be conducted to validate these findings. Here we describe the adaptation of an existing validated automated CTC assay to detect CMC in the blood of patients diagnosed with malignant melanoma and its potential use as a means of predicting clinical outcomes.

\section{Materials and methods}

Patients and blood collection. Blood was drawn from healthy volunteers and patients with malignant melanoma into evacuated $10-\mathrm{ml}$ blood CellSave preservative blood draw tube (Veridex LLC, Raritan, NJ) and processed within $72 \mathrm{~h}$. The patients were all enrolled from the Department of Medical Oncology of the University of Oxford at the Churchill Hospital using a research ethics committee approved protocol. All patients provided written informed consent. Forty-four patients were enrolled, 25 males and 19 females, and their age ranged from 31-81 (mean 59). At the time of first blood collection $39 / 44(86 \%)$ had metastatic disease and 5 patients had unresected stage III disease. Of the patients with metastatic disease 38/44 (78\%) had visceral disease, 5/44 (11\%) had no visceral involvement and for 1 patient the metastatic sites were not recorded. Median duration of follow-up was 10.1 months. Blood was always drawn from cancer patients either before or a minimum of 7 days after the administration of intravenous therapy. Fifty-five healthy volunteers were included as controls and had no known illness or fever at the time of blood sampling and no history of malignant disease.

Cell culture and cell spiking. The melanoma cell line SKMel28 was cultured in flasks containing RPMI-1640 supplemented with $10 \%$ fetal calf serum and subsequently harvested 
without trypsinization. The cell suspensions were only used when their viability as assessed by trypan blue exclusion exceeded $90 \%$. To determine the actual cell number, $200 \mu 1$ of buffer and $20 \mu \mathrm{l}$ of fluorescent beads (Beckman-Coulter, Inc., Miami, FL) containing approximately 20,000 total beads were added to a $50 \mu 1$ aliquot of the SK-Mel28 cells. The SK-Mel28 cells were stained with anti-HMW-MAA conjugated to PE for the detection. Duplicate tubes containing beads only were run on a flow cytometer (FACSCalibur; BD Biosciences, San Jose, CA) until $100 \%$ of the sample was aspirated. This provided an accurate estimate of the number of beads present in $20 \mu 1$. The experimental tubes were then tested in triplicate on the flow cytometer until 10,000 beads were counted in each tube. The number of SK-Mel28 cells was determined using the known number of beads per unit volume.

Sample preparation. Blood $(7.5 \mathrm{ml})$ is transferred to $15 \mathrm{ml}$ CellTracks AutoPrep ${ }^{\circledR}$ sample tubes and mixed with $6.5 \mathrm{ml}$ of buffer, centrifuged at $800 \mathrm{x}$ g for $10 \mathrm{~min}$, and then placed on the CellTracks ${ }^{\circledR}$ AutoPrep ${ }^{\circledR}$ (Veridex LLC) for automated sample preparation (14). Reagents were optimized for capture and detection of melanoma cells and consisted of ferrofluids coated with CD146 antibodies to immunomagnetically enrich both melanoma cells and endothelial cells (15-19), a capture enhancement reagent to maximize the capture efficiency (20), a phycoerythrin-conjugated antibody that binds to the high molecular weight melanoma associated antigen (HMW-MAA) (clone 9.2.27, Veridex LLC) to identify melanoma cells (12,21-23), a mixture of two allophycocyanine-conjugated antibodies to identify leukocytes (CD45, clone HI30, Veridex LLC) and endothelial cells (CD34, clone 581, BD Biosciences), a FITC-conjugated antibody identifying the Ki67 protein (clone B56, BD Biosciences), the nuclear dye 4',6-diamidino2-phenylindole (DAPI) to identify nucleated cells and buffers to wash, permeabilize and resuspend the cells. In the final processing step, the cells were resuspended in the MagNest ${ }^{\circledR}$ cell presentation device (Veridex LLC). The magnetic field generated by the MagNest device causes the magnetically labeled cells to distribute uniformly over the analysis surface of the cartridge, ready for analysis using the CellTracks Analyzer $\mathrm{II}^{\circledR}(24)$.

Sample analysis. The MagNest is placed on the CellTracks Analyzer II, a four-color semi-automated fluorescence microscope. Image frames covering the entire surface of the cartridge for each of the four fluorescent filter cubes are captured. Images that contain PE as well as DAPI-positive events are presented in a gallery for classification of the events by the user based on cell fluorescence and morphology. The criteria for an object to be defined as a melanoma cell include round to oval morphology, a visible nucleus (DAPI positive), positive staining for HMW-MAA and negative staining for CD45 and CD34. The melanoma cells were divided in $\mathrm{KI} 67^{+}$and Ki67- cells. Results of cell enumeration are always expressed as the number of cells per $7.5 \mathrm{ml}$ of blood.

Accuracy, sensitivity and linearity of melanoma cell detection. For accuracy, linearity and sensitivity experiments, SK-

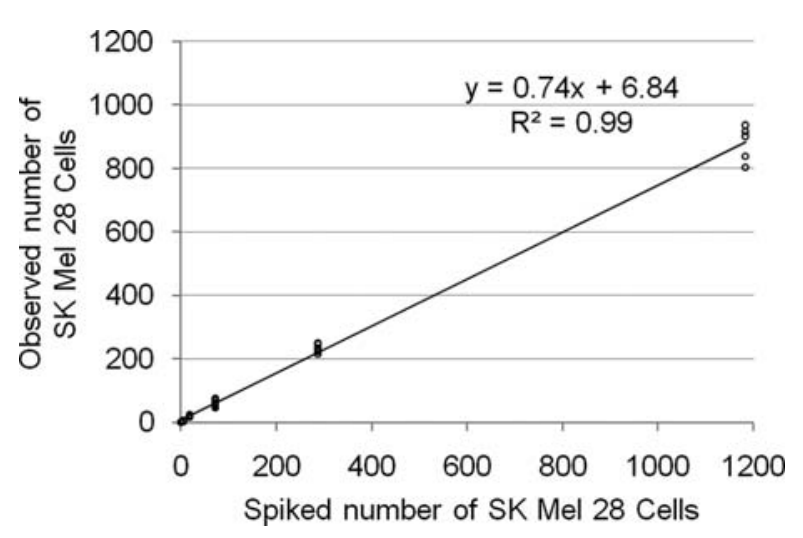

Figure 1. Recovery of known numbers of spiked SK-Mel 28 cells from whole blood. SK-Mel28 cells spiked into the healthy donor samples (i.e., 0 , $5,18,72,280$ and 1183 cells were spiked into $7.5 \mathrm{ml}$ of blood from five healthy donors on each of 2 days with a total of 6 different samples at each cell level). The number of cells spiked is plotted versus the observed number of cells recovered.

Mel28 cells were spiked into $7.5 \mathrm{ml}$ of blood collected into CellSave preservative tubes at 6 different levels of cells $(0,5$, $18,72,280$ and 1183). The exact number of cells spiked into blood was determined by flow cytometry. The samples were processed $24 \mathrm{~h}$ after spiking the blood on a CellTracks AutoPrep and analyzed with a CellTracks Analyzer II. Sample testing was performed over two different days with a total of 5 different samples at each cell level.

Statistical analysis. The primary end-point was overall survival, measured as the time from the sample date to date of death from any cause. Patients who were lost to follow-up or still alive at the end of study were censored at the last date they were known to be alive or at the end of study date. If there were multiple samples per patient, the last sample was used for survival analysis. Overall survival was calculated using the Kaplan-Meier method and a survival plot was generated. Cox regression models was used to determine hazard ratios (HR) of death. Results were analyzed in SPSS 16.0 (SPSS Inc., Chicago, IL, USA).

\section{Results}

Assay performance using whole blood-spiked with SK-Mel28 cells. Whole blood was drawn into CellSave tubes from healthy volunteers and spiked with tissue culture melanoma SK-Mel28 cells. Varying numbers of SK-Mel28 cells were spiked into blood, and recovery was measured. The expected number of SK-Mel28 cells spiked into the healthy donor samples (i.e., 0, 5, 18, 72, 280 and 1183 cells) plotted against the actual number of SK-Mel28 cells observed in the samples is shown in Fig. 1, and results are summarized in Table I. Mean recovery of spiked cells was $88 \%$, with recovery of $74 \%$ at the highest spike versus $88 \%$ at the 5 SK-Mel28 spike. Pearson $\mathrm{R}^{2}$ correlation was 0.99 . As expected, the coefficient of variation $(\mathrm{CV})$ increased as the number of cells spiked decreased, ranging from $7 \%$ at the 1,200-cell spike to $31 \%$ at the 5-cell spike. The recovery of SK-Mel28 cells ranged from 64 to $120 \%$ and did not decrease with lower cell numbers. 
Table I. Method accuracy measured by recovery of SK-Mel 28 cells spiked into $7.5 \mathrm{ml}$ blood of five healthy donors.

\begin{tabular}{cccccccc}
\hline & \multicolumn{3}{c}{ Observed CMC count } & & \multicolumn{3}{c}{$\%$ Recovery } \\
\cline { 2 - 3 } Expected CMC count & Average & SD & $95 \% \mathrm{CI}$ & & Average & $95 \% \mathrm{CI}$ & $\% \mathrm{CV}$ \\
\hline 0 & 0 & 0 & 0 & & 0 & 0 & 0 \\
5 & 4 & 1 & $3-5$ & & 88 & $64-112$ & 31 \\
18 & 20 & 2 & $18-22$ & & 110 & $100-120$ & 10 \\
72 & 63 & 11 & $53-73$ & & 87 & $74-100$ & 17 \\
287 & 234 & 15 & $221-247$ & & 81 & $77-85$ & 6 \\
1183 & 880 & 56 & $831-929$ & & 74 & $70-78$ & 7 \\
\hline
\end{tabular}

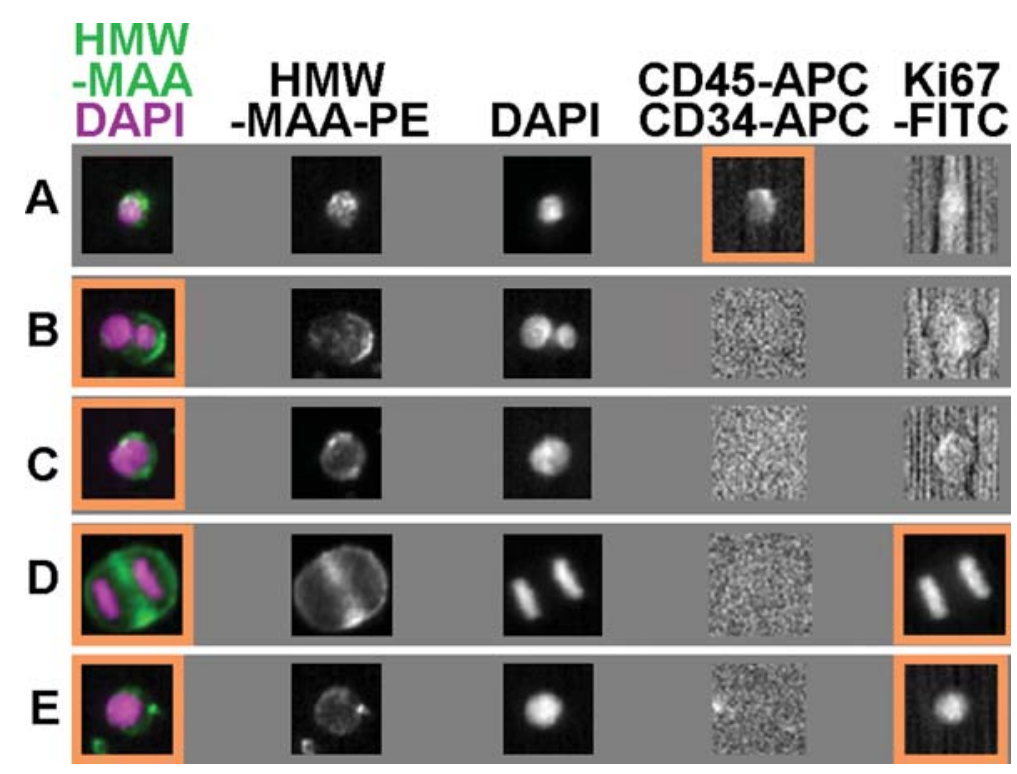

Figure 2. Rows A-E represent objects that were identified by the CellTracks Analyzer II software as objects having both DAPI and PE signal in a sample from a melanoma patient. From right to left the thumbnail images represent the Ki67 FITC signal, the CD45 and or CD34 APC signal, the DAPI signal, the HMWMAA PE signal and the overlay of DAPI (purple) and HMW-MAA (green) signal. The cell in row A is excluded as a melanoma cell as it expresses CD45 and or CD34, the cell in rows B and C are classified as melanoma cells that do not express Ki67 and the cell in rows D and E are classified as melanoma cells that do express Ki67.

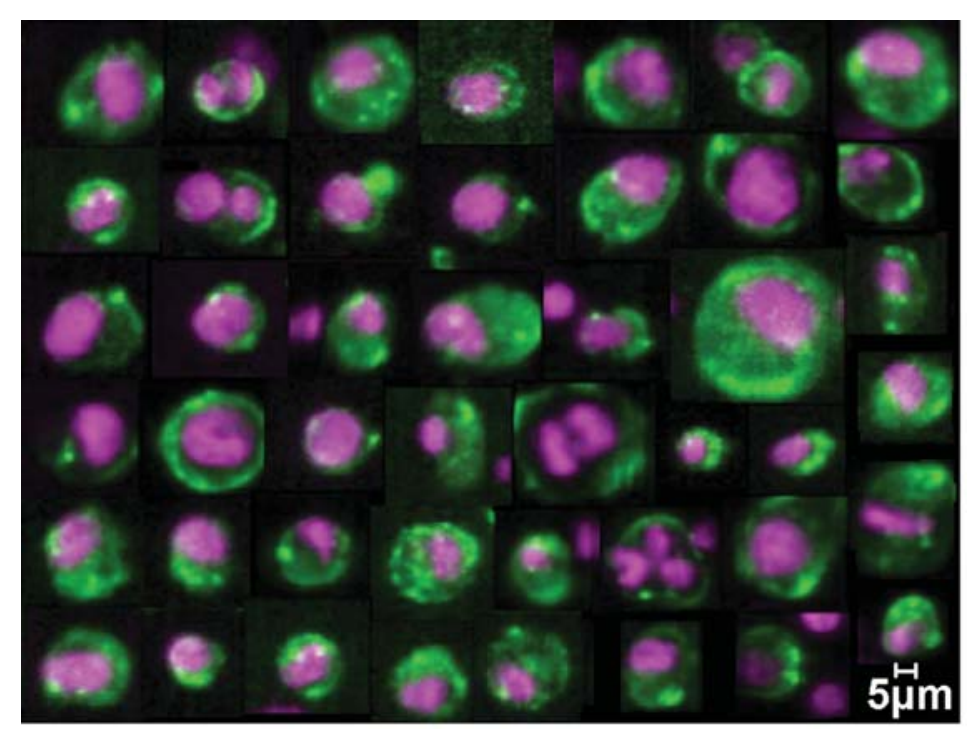

Figure 3. Gallery of typical CMC images from the CellTracks Analyzer II obtained from $7.5 \mathrm{ml}$ of blood from melanoma patients. 


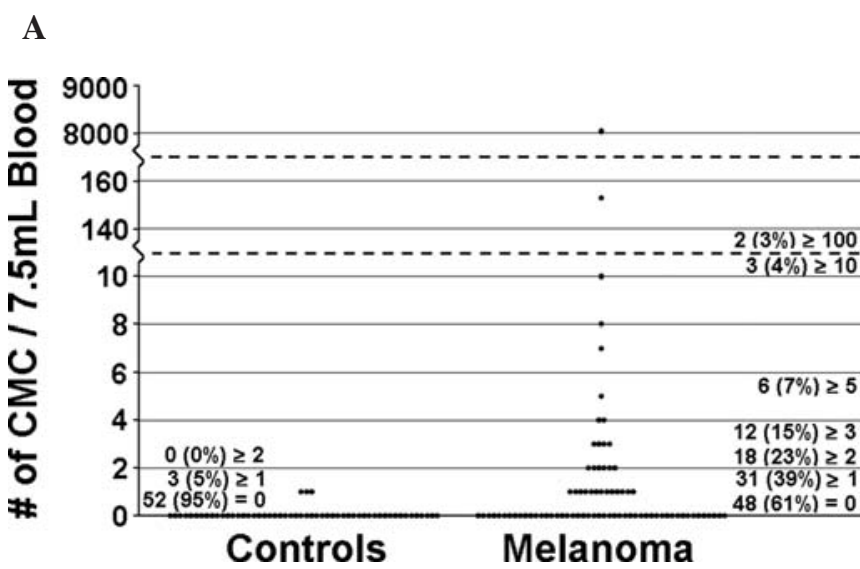

B

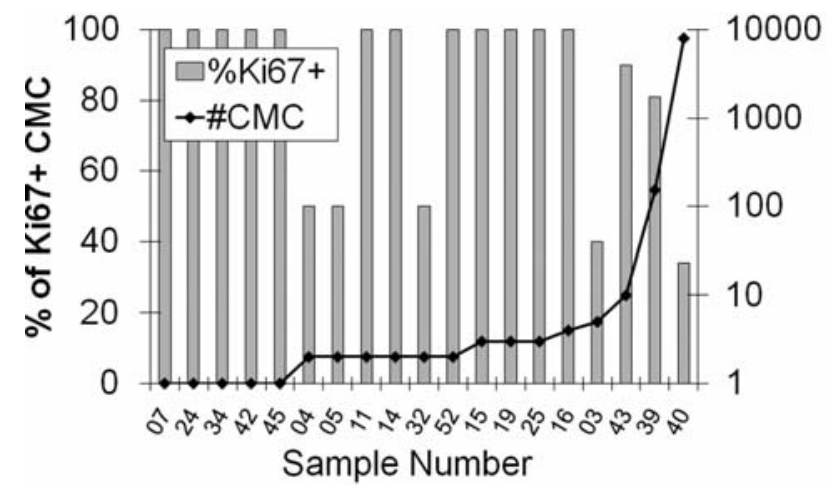

Figure 4. Prevalence of CMC in $7.5 \mathrm{ml}$ of blood of 55 healthy donors, 79 samples from 44 metastatic melanoma patients (A) and the percentage of Ki67 expressing CMC in 19 samples from 16 melanoma patients (B).

Identification of circulating melanoma cells. Thumbnail images of an overlay of HMW-MAA PE and HMW-MAA PE, DAPI, CD45/CD34 APC and Ki67 are presented to the operator for review. The presence of a nucleus, expression of HMW-MAA, cellular morphology, and a lack of CD45 or CD34 expression are the required characteristics of CMC. Fig. 2 shows 5 events from one melanoma patient that are presented to the reviewer. Fig. 2A shows a cell staining with DAPI and HMW-MAA, but also with CD34 and or CD45 and is thus not classified as CMC. Fig. 2B-E show cells staining with DAPI and HMW-MAA, but not with CD34 or CD45 and are classified as CMC. The CMC in Fig. 2B and $\mathrm{C}$ do not express Ki67 whereas the CMC in Fig. 2D and E do. Note that the CMC in Fig. 2B contains two nuclei and does not stain with Ki67 whereas the CMC in Fig. 2D appears to be actively dividing and indeed expresses Ki67. The size of the $\mathrm{CMC}$ and their nuclear to cytoplasmic ratio vary greatly between $\mathrm{CMC}$ within and between melanoma patients. Fig. 3 shows a gallery of CMC images from different patients with characteristically a round to oval shape and an intact nucleus. Cellular sizes varied over a wide range from 4 to $30 \mu \mathrm{m}$. Small cell clusters and multinucleated CMC were also observed.

Circulating melanoma cells in healthy volunteers and melanoma patients. CMC were enumerated in 55 blood samples

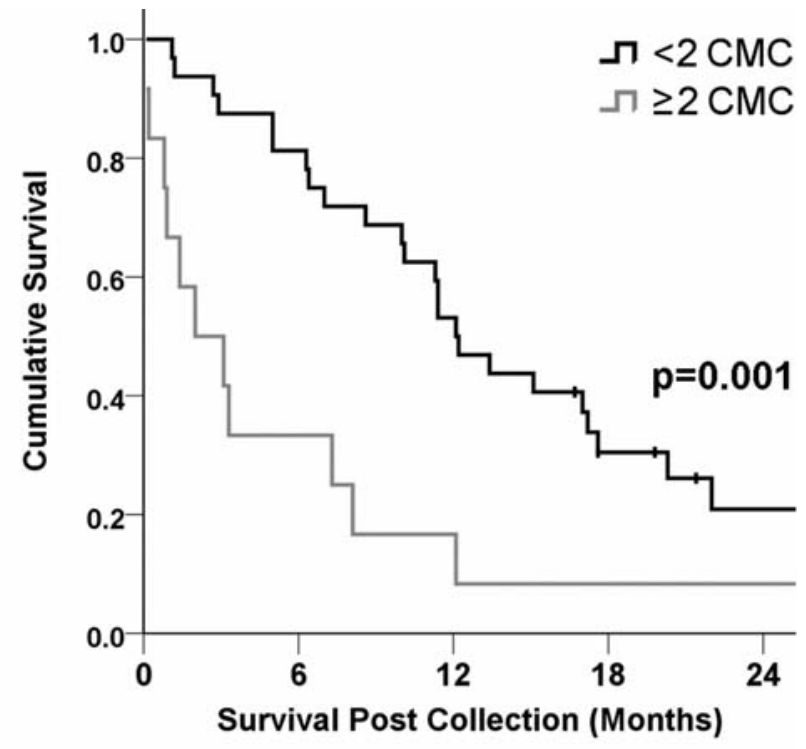

No. at risk

$\begin{array}{rrrrr}<2 \text { CMC } 32 & 26 & 17 & 8 & 4 \\ \geq 2 \text { CMC } 12 & 4 & 2 & 1 & 1\end{array}$

Figure 5. Kaplan-Meier estimates of probabilities of overall survival in patients with metastatic melanoma for those with $<2$ circulating melanoma cells per $7.5 \mathrm{ml}$ of whole blood and those in the group with $\geq 2$ circulating melanoma cells in $7.5 \mathrm{ml}$ of whole blood. OS times were calculated from the time of each blood draw. Median survival is 12.1 months for the group with $<2 \mathrm{CMC}$ versus 2.0 months for those with $\geq 2 \mathrm{CMC}$ ( $\mathrm{P}=0.001$ by the $\log$ rank test; hazard ratio of death in patients with $\geq 2$ cells per $7.5 \mathrm{ml}, 3.2$ ).

from healthy donors and 79 samples from 44 patients with metastatic melanoma. Fig. 4A shows the number of CMC detected in $7.5 \mathrm{ml}$ of blood of the control group and the patients. Assessment of Ki67 expression was determined in 19 samples from 17 patients in whom CMC were detected. The percentage of $\mathrm{Ki} 67+\mathrm{CMC}$ ranged from 34 to $100 \%$ with a mean of $84 \%$ (SD25). Fig. 4B shows the Ki67 expression and the number of CMC detected in these samples. In the 55 healthy donors three cells were classified as CMC and none of them expressed Ki67.

Circulating melanoma cells and overall survival in melanoma patients. None of the individuals in the control group had 2 or more CMC detected and this cut-off was chosen to discriminate between patient groups. Mean OS time for those patients with <2 CMC was 12.1 months (95\% CI 9.7-14.4) and was significantly longer than the median OS time for those patients with $\geq 2$ CMC, 2.0 months (95\% CI 0-4.9) (Fig. 5). Log-rank, $\mathrm{p}=0.001$. Hazard ratio of death was 3.2 (95\% CI 1.6-6.5) by Cox regression analysis. The four patients who died within 1 month after blood drawal had 2, 8, 10 and $8043 \mathrm{CMC} / 7.5 \mathrm{ml}$.

\section{Discussion}

Current staging modalities of melanoma patients are inadequate for optimal therapeutic management as disease recurrence is observed in many patients after treatment. Several studies have shown that detection of CMC may represent a bio- 
marker that can identify metastatic disease spread and may be used to monitor the effectiveness of the treatment (10-13). Unfortunately, the methodologies used to identify the presence of CMC have not been standardized which hinders the ability to conduct multicenter studies and the implementation in routine clinical practice.

Herein we introduce a CMC enumeration assay that is linear over the tested range from 0 to $1200 \mathrm{CMC}$ and can detect $1 \mathrm{CMC}$ in $7.5 \mathrm{ml}$ of blood. In $23 \%$ of melanoma patients $\geq 2 \mathrm{CMC}$ and in $0 \%$ of normal healthy donors $\geq 2$ $\mathrm{CMC}$ are detected. Spiking experiments conducted with the melanoma cell line SK-Mel28 show that the recovery is approximately $88 \%$. The majority of CMC with a similar density of CD146 and HMW-MAA will thus be identified. The frequency of CMC that do not express both antigens is not known. Addition of HMW-AA antibodies or Mart 1 antibodies 25-27 to the ferrofluids to improve CMC capture or to the detection antibodies to improve CMC detection neither improved the yield of the spiked CMC nor the detection of CMC in patient samples (data not shown). Although sensitivity can be increased by sampling larger blood volumes one quickly reaches the limit of the amount of blood that one can sample. Alternative means to sample larger volumes are to develop in vivo detection methods for CMC and a first attempt for an in vivo non-invasive method looks promising (28).

To determine whether or not CMC are actively dividing we assessed the expression of the proliferation-associated protein Ki67. Surprisingly 84\% of CMC expressed Ki67 and in 12/19 (63\%) melanoma patients all CMC expressed Ki67. This is in stark contrast with CTC in metastatic prostate and breast cancer from which a significant portion is undergoing apoptosis $(29,30)$. The level of expression of Ki67 on melanoma cells has been associated with the aggressiveness of the disease (31-34). The reported percentages of Ki67+ melanoma cells in primary and metastatic lesions in these studies are smaller as compared to the proportion of $\mathrm{Ki}^{+} 7^{+}$ CMC suggesting that these CMC indeed represent very aggressive cells.

The primary objective of this study was to develop a standardized method for the enumeration of CMC, the number of patients in this study was thus not powered for survival analysis nor was the sampling of blood controlled for line of therapy or with respect to the timing in relation to treatment administration. Nevertheless the association between the presence of $\mathrm{CMC}$ and relative short survival was quite strong in these patients. The ultimate demonstration of the prognostic and predictive value of the presence of CMC will need to come from controlled prospective clinical studies.

\section{Acknowledgments}

This study was sponsored by AstraZeneca. Twente University has a technology and development agreement with Veridex LLC. L.W.M.M. Terstappen is an advisor for Veridex LLC and Gerald Doyle was an advisor for Veridex LLC. Chandra Rao and Mark Connelly are employees of Veridex LLC. Thai Bui is a contract employee at Veridex LLC. Glen Clack and Michael Malone are employees of AstraZeneca.

\section{References}

1. Allard WJ, Matera J, Miller MC, Repollet M, Connelly MC, Rao C, Tibbe A, Uhr JW and Terstappen LWMM: Tumor cells circulate in the peripheral blood of all major carcinomas but not in healthy subjects or patients with non-malignant diseases. Clin Cancer Res 10: 6897-6904, 2004.

2. Cristofanilli M, Budd GT, Ellis MJ, Stopeck A, Matera J, Miller MC, Rueben JM, Doyle G, Allard WJ, Terstappen LWMM and Hayes DF: Circulating tumor cells, disease progression and survival in metastatic breast cancer. N Engl J Med 351: 781-791, 2004.

3. Cohen SJ, Punt CJA, Iannotti N, Saidman BH, Sabbath KD, Gabrail NY, Picus J, Morse M, Mitchell E, Christopher E, Desch, Miller MC, Doyle GV, Tissing H, Terstappen LWMM and Meropol NJ: The relationship of circulating tumor cells to tumor response, progression-free survival, and overall survival in patients with metastatic colorectal cancer. J Clin Oncol 26: 3213-3221, 2008.

4. DeBono JS, Scher HI, Montgomery RB, Parker C, Miller MC, Tissing H, Doyle GV, Terstappen LWWM, Pienta KJ and Raghavan D: Circulating tumor cells (CTC) predict survival benefit from treatment in metastatic castration resistant prostate cancer (CRPC). Clin Cancer Res 14: 6302-6309, 2008.

5. Riethdorf S, Fritsche H, Muller V, Rau T, Schindlbeck C, Rack B, Janni W, Coith C, Beck K, Jänicke F, Jackson S, Gornet T, Cristofanilli $\mathrm{M}$ and Pantel $\mathrm{K}$ : Detection of circulating tumor cells in peripheral blood of patients with metastatic breast cancer: A validation study of the CellSearch system. Clin Cancer Res 13: 920-928, 2007.

6. Tol J, Koopman M, Miller MC, Tibbe A, Cats A, Creemers GJM, Vos AH, Nagtegaal ID, Terstappen LWMM and Punt CJA: Circulating tumour cells early predict progression-free and overall survival in advanced colorectal cancer patients treated with chemotherapy and targeted agents. Ann Oncol 21: 1006-1012, 2010.

7. Liu MC, Shields PG, Warren RD, Cohen P, Wilkinson M, Ottaviano YL, Rao SB, Eng-Wong J, Seillier-Moiseiwitsch F, Noone A and Isaacs C: Circulating tumor cells: A useful predictor of treatment efficacy in metastatic breast cancer. J Clin Oncol 27: 5153-5159, 2009.

8. Budd G, Cristofanilli M, Ellis M, Stopeck A, Borden E, Miller MC, Matera J, Repollet M, Doyle G, Terstappen LWMM and Hayes D: Circulating tumor cells versus imaging-predicting overall survival in metastatic breast cancer. Clin Cancer Res 12: 6404-6409, 2006.

9. De Giorgi U, Valero V, Rohren E, Dawood S, Ueno NT, Miller MC, Doyle GV, Jackson S, Andreopoulou E, Handy BC, Reuben JM, Fritsche HA, Macapinlac HA, Hortobagyi GN and Cristofanilli M: Circulating tumor cells and [18F]fluorodeoxyglucose positron emission tomography/computed tomography for outcome prediction in metastatic breast cancer. J Clin Oncol 27: 3303-3311, 2009.

10. Koyanagi K, O'Day SJ, Gonzalez R, Lewis K, Robinson WA, Amatruda TT, Wang HJ, Elashoff RM, Takeuchi H, Umetani N and Hoon DSB: Serial monitoring of circulating melanoma cells during neoadjuvant biochemotherapy for stage III melanoma: outcome prediction in a multicenter trial: J Clin Oncol 23: 8057-8064, 2005

11. Mocellin S, Hoon D, Ambrosi A, Nitti D and Rossi CR: The prognostic value of circulating tumor cells in patients with melanoma: A systematic review and meta-analysis. Clin Cancer Res 12: 4605-4613, 2006.

12. Ulmer A, Schmidt-Kittler O, Fischer J, Ellwanger U, Rassner G, Riethmuller G, Fierlbeck G and Klein CA: Immunomagnetic enrichment, genomic characterization, and prognostic impact of circulating melanoma cells. Clin Cancer Res 10: 531-537, 2004.

13. Ulmer A, Beutel J, Susskind D, Hilgers RD, Ziemssen F, Luke M, Rocken M, Rohrbach M, Fierlbeck G, Bartz-Schmidt KU and Grisanti S: Visualization of circulating melanoma cells in peripheral blood of patients with primary uveal melanoma. Clin Cancer Res 14: 4469-4474, 2008.

14. Kagan M, Howard D, Bendele T, Mayes J, Silvia J, Repollet M, Doyle J, Allard J, Tu N, Bui T, Russell T, Rao C, Hermann M, Rutner $\mathrm{H}$ and Terstappen LWMM: A sample preparation and analysis system for identification of circulating tumor cells. J Clinical Ligand Assay 25: 104-110, 2002.

15. Hsu MY, Meier F and Herlyn M: Melanoma development and progression: a conspiracy between tumor and host. Differentiation 70: 522-536, 2002. 
16. Johnson JP: Cell adhesion molecules in the development and progression of malignant melanoma. Cancer Metastasis Rev 18: 345-357, 1999.

17. Mills L, Tellez C, Huang S, Baker C, McCarty M, Green L, Gudas JM, Feng X and Bar-Eli M: Fully human antibodies to MCAM/MUC18 inhibit tumor growth and metastasis of human melanoma. Cancer Res 62: 5106-5114, 2002.

18. Shih IM: The role of CD146 (Mel-CAM) in biology and pathology. J Pathol 189: 4-11, 1999.

19. Rowand JL, Martin G, Doyle GV, Miller MC, Pierce MS, Connelly MC, Rao C, Terstappen LWMM: Endothelial cells in peripheral blood of healthy subjects and patients with metastatic carcinomas. Cytometry A 71: 105-113, 2007.

20. Liberi PA, Rao CG and Terstappen LWMM: Optimization of ferrofluids and protocols for the enrichment of breast tumor cells in blood. J Magnetism Magnetic Materials 225: 301-307, 2001.

21. Bumol TF and Reisfeld RA: Unique glycoprotein-proteoglycan complex defined by monoclonal antibody on human melanoma cells. Proc Natl Acad Sci USA 79: 1245-1249, 1982.

22. Pluschke G, Vanek M, Evans A, Dittmar T, Schmid P, Itin P Filardo EJ and Reisfeld RA: Molecular cloning of a human melanoma-associated chondroitin sulfate proteoglycan. Proc Natl Acad Sci USA 93: 9710-9715, 1996.

23. Yang J, Price MA, Neudauer CL, Wilson C, Ferrone S, Xia H, Iida J, Simpson MA and McCarthy JB: Melanoma chondroitin sulfate proteoglycan enhances FAK and ERK activation by distinct mechanisms. J Cell Biol 21: 881-891, 2004.

24. Tibbe AGJ, de Grooth BG, Greve J, Dolan GJ, Rao C and Terstappen LWMM: Magnetic field design for selecting and aligning immunomagnetic labeled cells. Cytometry 47: 163-172, 2002 .

25. Beaty MW, Fetsch P, Wilder AM, Marincola F and Abati A: Effusion cytology of malignant melanoma. A morphologic and immunocytochemical analysis including application of the MART-1 antibody. Cancer 81: 57-63, 1997.

26. Hoashi T, Watabe H, Muller J, Yamaguchi Y, Vieira WD and Hearing VJ: MART-1 is required for the function of the melanosomal matrix protein PMEL17/GP100 and the maturation of melanosomes. J Biol Chem 280: 14006-14016, 2005.
27. Zubovits J, Buzney E, Yu L and Duncan LM: HMB-45, S-100, NK1/C3, and MART-1 in metastatic melanoma. Hum Pathol 35: 217-23, 2004.

28. Galanzha EI, Shashkov EV, Spring PM, Suen JY and Zharov VP: In vivo, noninvasive, label-free detection and eradication of circulating metastatic melanoma cells using two-color photoacoustic flow cytometry with a diode laser. Cancer Res 69: 7926-7934, 2009.

29. Larson CJ, Moreno JG, Pienta KJ, Gross S, Repollet M, O'Hara SM, Russell T and Terstappen LWMM: Apoptosis of circulating tumor cells in prostate cancer patients. Cytometry 62A: 46-53, 2004.

30. Smeradge J, Doyle GV, Repollet M, Terstappen LWMM, Hayes D: Apoptosis and Bcl-2 expression of circulating tumor cells in metastatic breast cancer. Proc Annu Meet Am Assoc Cancer Res 47: A792, 2006.

31. Moretti S, Massbrio R, Brogelli L, Novelli M, Giannotti B and Bernengo MG: Ki67 antigen expression correlates with tumor progression and HLA-DR antigen expression in melanocytic lesions. J Invest Dermatol 95: 320-324, 1990.

32. Ben-Izhak O, Bar-Chana M, Sussman L, Dobiner V, Sandbank J, Cagnano M, Cohen H and Sabo E: Ki67 antigen and PCNA proliferation markers predict survival in anorectal malignant melanoma. Histopathology 41: 519-525, 2002.

33. Gimotty PA, Van Belle P, Elder DE, Murry T, Montone KT, $\mathrm{Xu}$ X, Hotz S, Raines S, Ming ME, Wahl P and Guerry DP: Biologic and prognostic significance of dermal Ki67 expression, mitoses, and tumorigenicity in thin invasive cutaneous melanoma. J Clin Oncol 23: 8048-8056, 2005.

34. Pearl RA, Pacifico MD, Richman PI, Stott DJ, Wilson GD and Grobbelaar AO: Ki-67 expression in melanoma. A potential method of risk assessment for the patient with a positive sentinel node: J Exp Clin Cancer Res 26: 109-115, 2007. 